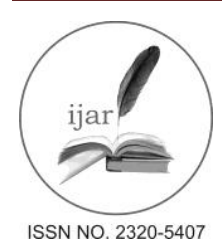

Journal homepage: http://www.journalijar.com

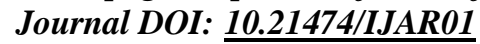

INTERNATIONAL JOURNAL

OF ADVANCED RESEARCH

RESEARCH ARTICLE

\title{
ATTEMPT IN CRIMINAL LAW OF THE REPUBLIC OF UZBEKISTAN.
}

Kamalova Dildora Gayratovna.

Senior teacher of the department, Criminal Law and Criminology, Tashkent State University of Law, the Republic of Uzbekistan.

\section{Manuscript Info}

\section{Manuscript History:}

Received: 12 May 2016

Final Accepted: 19 June 2016

Published Online: July 2016

Key words:

uncompleted crime, criminal attempt, objective signs, subjective

signs, completed attempt,

uncompleted attempt, criminal

liability, direct intent.

*Corresponding Author

(............................

Kamalova Dildora

Gayratovna

\section{Abstract}

This article is dedicated to the institute of criminal attempt. The criminal attempt is one of the complicated and important institutes of Criminal law. The correct sentencing for the acts crime interrupted before the commission thereof due to circumstances not depending of a committer person is an expression of priority Principle of Criminal law - principle of Lawfulness. Therefore, researching of legal nature of criminal attempt, analyzing its objective and subjective signs has a very special significance. The author reveals the social danger of criminal attempt, necessity of appointing the criminal responsibility for it. Such types of criminal attempt like completed, uncompleted, fit and unfit criminal attempt are analyzed. On the base of Criminal Code of the Republic of Uzbekistan, recites the problems of sentencing for the criminal attempt as well as given the recommendations for improving and further liberating of criminal legislation.

signs.

Copy Right, IJAR, 2013,. All rights reserved.

\section{Introduction:-}

In the Republic of Uzbekistan, consistently and gradually move the processes of deepening of judicial reforms and modernization of the country. The primary goal of judicial reforms - on the one hand, strengthening the status of the judiciary as an effective means to protect the rights, freedoms and lawful interests of citizens, and secondly, to ensure genuine independence of the judge, increasing the role in the formation of a humane, democratic state and civil society.

The Criminal Code of the Republic of Uzbekistan, adopted on 22 September 1994 and comed into force on 1 April 1995 , it is the only source of criminal law. It should be noted, that the criminality, penality and other legal consequences of the criminal act are determined only by the Criminal Code of the Republic of Uzbekistan.

The aim of the Criminal Code is to protect the individual, his rights and freedoms, interests of society and the state from criminal encroachments. A person who commits a crime, in order to achieve the result of a criminal commits certain acts and wants to attack criminal consequences. But, in some cases as a result of these acts a person does not achieve his pursued aim. Although in such cases there is no encroachment on the specific social relations, it is not harmful, but there is a public danger. Therefore, the criminal law establishes criminal liability for an uncompleted crime - preparation for crime and criminal attempt.

\section{The concept and legal signs of a Criminal Attempt}

Article 25 of the chapter "Uncompleted crime" of the Criminal Code defines the concepts of preparation for crime and criminal attempt. Preparation for crime deemed an act of the person creating the conditions for committing or concealing an intentional crime, interrupted before the commission thereof due to circumstances not depending of a committer. A Criminal Attempt is considered the beginning of the commission of an intentional crime uncompleted thereof due to circumstances not depending of a committer. 
Article 24 of the Constitution it is determined that the right to life is an inalienable right of every human. Encroachment on life is a grave crime ${ }^{1}$. In this norm the term "encroachment" used in the sense of an assassination attempt, intent on human life, attempt of Intentional Killing. This concept also means a similar sense in the Criminal Code of the Republic of Uzbekistan.

The word 'attempt', said chief justice Cockburn, clearly conveys with it the idea that if the attempt had succeeded, the offence charged would have been committed. In other words, attempt is the direct movement towards the commission of an offence after the preparation has been made. According to English law, a person may be guilty of an attempt to commit an offence, if he does an act which is more than merely preparatory to the commission of the offence and a person may be guilty or attempt to commit an offence even though the facts are such that the commission the offence is impossible ${ }^{2}$.

In accordance with Article 14 of the Criminal Code of the Republic of Uzbekistan, A culpable socially dangerous act (action or inaction) prohibited by this Code on pain of imposing of a penalty shall be recognized as a crime. So, according to this definition, any action or inaction shall be recognized as a crime only in the presence of public danger, illegality, guilt, penality. This rule applies in relation to uncompleted crime.

Criminal Attempt is socially dangerous (causes or a real threat of damage to social relations, protected by the Criminal Code), illegal (prohibited by the Criminal Code), punishable (shall be punished in accordance with articles 54, 58 of the Criminal Code), guilty (conscious volitional activity entity) act.

Attempt is the direct movement towards the commission of an offence after the preparation is made ${ }^{3}$. Attempt - an action (inaction) directly aimed at the commission of an offence, which is not brought to an end due to circumstances not depending of a committer, or onset of action (or inaction) directly aimed at the commission of an offence and contains a specific objective evidence of a crime ${ }^{4}$.

Attempt is the second stage of the commission of the offense, a conscious action, reflecting the objective side of an offence to commit a crime and the attainment of socially dangerous consequences, which finished due to circumstances not depending of a committer. Attempt is the second stage of the crime characterized by the beginning of the crime. At the stage of committing a criminal attempt is carried out part of the objective side of a particular crime, it is the action or inaction referred in the disposition of the article of the Special Part of Criminal Code is carried out in full or in part, however, the criminal result is not achieved. Under the criminal result should be understood not only the consequences of criminal offenses with the material composition, but also uncompleted perform actions or inactions referred to the crimes with the formal composition.

"The offense and the composition of offense (corpus delicti) - it is an objective reality, a legal act of the human mind. Signs of crime are the most important features of a crime, precisely defined in the law. An element of a crime, in turn - it is an integral part of the composition of crime, covering a group of signs (elements) of a certain side of a socially dangerous act, recognized by law as a crime. The composition of each crime consists of the objective and subjective sides, covering a set of signs reflect the relevant objective and subjective side of the crime ${ }^{5}$. Therefore, in our view, the signs of the attempt to commit a crime should be analyzed by separating the objective and subjective signs. Such, M.H.Rustambaev and E.O.Turgunboev include the following in objective signs of an criminal attempt: - the beginning of the crime that is committed actions (inaction), provided for in the specific objective signs of a particular crime, according to E.O.Turgunboev, performed part of the signs of the objective side of an offence, provided for in the disposition of one of the norms of the Special Part of Criminal Code;

- incompleted attempt;

- interrupting of offence before the commission thereof due to circumstances not depending of a committer"

\footnotetext{
${ }^{1}$ The Constitution of the Republic of Uzbekistan adopted on december 8, 1992 at the eleventh session of the Supreme council of the Republic of Uzbekistan of the Twelfth convocation.

${ }^{2}$ Gaur K.D. , " Indian Penal Code” Chap.XXIII p. 842

${ }^{3}$ Attempt in Criminal law. By Suwarn Rajan, Advocate, Supreme Court of India. Published in Criminal Law Journal. http://www.lawyersclubindia.com

${ }^{4}$ Rustambayev M.X. The Republic of Uzbekistan Criminal Law course. -Tashkent. Ilm Ziyo. 2010, P.246.

${ }^{5}$ Usmonaliyev M. The composition of offense (corpus delicti). -Tashkent: TSIL, 2008. -P.8.

${ }^{6}$ Turgunboyev E.O. The foundation of qualifing act as a criminal attempt // The bulletin of Supreme Court of the Republic of Uzbekistan 2008, №5. -P.35.; Rustambayev M.X. The Republic of Uzbekistan Criminal Law course. -Tashkent. Ilm Ziyo. 2010, -P.246.
} 
According to English law, a person may be guilty of an attempt to commit an offence if he does an act which is more than merely preparatory to the commission of the offence; and a person will be guilty of attempting to commit an offence even though the facts are such that the commission of the offence is impossible.

In English Law, there are three essentials of an attempt:-:

- Guilty intention to commit an offence; (called as mens rea)

- Some act done towards the commission of the offence (called as actus reus)

- $\quad$ The act must fall short of the completed offence ${ }^{1}$.

Criminal Attempt has existed since the beginning of the objective side of the crime provided for in the Special Part of the Criminal Code. In contrast to the completed crime, signs of the objective side of the Criminal Attempt fixed in the norms of General and Special parts of the Criminal Code.

The main sign of the objective side of the Criminal Attempt is a partial, incomplete fulfillment of the objective side of a particular offense referred to in the disposition of one of the articles of the Special parts of Criminal Code. In our opinion, the following objective signs of the Criminal Attempt can be pointed:

\section{Criminal Attempt has inflicted or a real threat of damage to social relations.}

The object of the crime is public relations, protected by criminal law, which made an attack or who are under real threat of infringement as a result of the commit an offence. The object of the Criminal Attempt are public relations, protected by criminal law, which causes or creates a real threat of damage in the committing of an action (or inaction) directly aimed at the offence. It should be noted that the amount of damage caused by the Criminal Attempt less than the damage caused by the insecurity completed crime. Due to the fact that Criminal Attempt is not destroyed completely the particular social relation, the law provides for a lighter sentence.

2. Criminal Attempt means directly beginning of the commission of a crime. Realization of actions (inaction) directly aimed at the commission of a crime provided for in the disposition of article of the Special Part of Criminal Code, recognized as a beginning of the crime.

At the stage of Criminal Attempt, it should not only be initiated, but with it must be committed some actions or inaction that are mandatory signs of the objective side of the offense.

3. Unfinishing of criminal act, - it means the absence of one or more mandatory signs of the offense provided for in particular norm by a Special Part of Criminal Code. The crimes with the formal composition of the action or inaction is not performed completely. That is, in the crimes with a complex structure, requiring the fulfillment of a number of actions to complete an offence, the action or inaction performed partially. The crimes of the material composition is not obtained criminal result, that is, as a result of action or inaction the will of criminal consequence does not occur, this effect should be mandatory sign the objective side of the crimes of which he was sent to the intention of the guilty person.

4. Uncompleted crime thereof due to circumstances not depending of a committer. The Criminal attempt does not end due to circumstances not depending of a committer, not because of fear of the committer from punishment, the voluntary refusal to commit a crime. In analyzing the causes of uncompleted crime, a group of scientists divide them to objective reasons, the other group - to subjective reasons, other scholars have identified both objective and subjective reasons.

Uncompleted crime does not depend on the committer. The reasons may be different: the absence of a crime subject, the presence of a crime subject to a lesser extent or volume, the resistance of the victim or other persons, useless weapons or means to commit the crime of criminal intent etc. At the same time, it is necessary to distinguish the complete of crime in the subjective sense of the actual criminal act uncompleted (lack of criminal consequences referred to in the criminal law). In most cases, in a criminal attempt occurs socially dangerous consequences, but it does not come committer wanted result. The attack does not make the act in the completed crime cause to qualify as a completed crime, need not attack any consequences, but the special consequences provided in the criminal law. Criminal Attempt can not be completed for subjective reasons: inexperience person, insufficient qualifications, no ability to aim and etc.

\footnotetext{
${ }^{1}$ Rajib Hassan The Elements and Stages of a Crime An Overview http://www.legalservicesindia.com/article/article/theelements-and-stages-of-a-crime-1228-1.html
} 
In our opinion, the Criminal Code, which defined uncompleted attempt on crime due to circumstances not depending of a committer, provided objective and subjective reasons. We think the objective reasons should be divided into direct and indirect objective reasons for objective reasons. The direct objective reasons straightly related to the person committing the act, they are circumstances that can be covered by a person's will (physical weakness). Indirect objective reasons means the situation arising in the course of the action irrespective of the will of the person (detention by law enforcement agencies, etc.).

If Article 9 of the Criminal Code it is determined that $\mathrm{f}$ person shall be subject to liability only for those socially dangerous acts, in commission of which his guilt has been proved in the procedure established by law, in accordance with Article 14 of the Criminal Code, the guilt is an integral and inseparable part of every crime. This fact puts the guilt, which is the main sign of the subjective side of the crime, for the level of a separate legal category. Therefore, the guilt, on the one hand, is a mandatory element of the subjective side of the crime as the base of criminal responsibility, on the other hand, recognizes the principle of criminal responsibility. In the analysis of the legal attributes of criminal attempt should be emphasized that guilt is its base. The problem of determining the subjective side in criminal attempt that is necessary to specify the form of guilt of offence.

Since the Criminal Code of the subjective aspect of the criminal attempt is expressed in the form of intent, the majority of scientists support the idea that the stage of criminal attempt possible in the commission of crimes involving both direct and indirect intent. It is worth noting that according to the meaning of Article 25 of the Criminal Code, criminal attempt committed intentionally. But, in the Resolution of the Plenum of the Supreme Court of the Republic of Uzbekistan dated September 24, 2004 "On judicial practice in cases of intentionally killing" №13 was explained that the criminal attempt for intentionally killing is possible only with direct intent when a committer was aware of the social danger of his actions, foresaw the death of the victim, and desired her attack, but death does not come by circumstances beyond his control (due to the active resistance of the victim, the intervention of others, the timely provision of medical care to the victim and others.). ${ }^{1}$ In our opinion, this is the correct explanation. Since the subjective sign of criminal attempt is characterized by the fact it can only be used in committing offenses with direct intent. Guilty person is aware of the social danger of his actions and wants to make it (the offense with the formal composition) a person is aware of the social danger of his actions, foresees its socially dangerous consequences and desired their occurrence (with the material composition of the crime). So, on the criminal attempt is committed only with direct intent. Direct intent differs from indirect intent on volitional characteristics. With indirect intent is realized the possibility of socially dangerous consequences, but the person does not desire their occurrence, and deliberately allow their advance. Only crimes with the material composition can be committed with indirect intent. Therefore, when a person acts without the intention to achieve certain effects, and offense shall not be brought to the end, criminal responsibility does not occur. We can not act without the desire result of this action. Socially dangerous acts are not committed with indirect intent. Indirect intent is observed only upon the occurrence of socially dangerous consequences, and then has a criminally-legal value. Therefore, in the commission of crimes with indirect intent can not stage of criminal attempt.

Thus, the following signs are considered subjective signs of the criminal attempt:

1. Criminal Attempt is committed with direct intent. Will the person is directed to perform a some offense under the Special Part of Criminal Code and aware of its dangerous nature and desired to perform the action (inaction) and bring it to the final result. Criminal Intent of person foresees the possibility or inevitability of socially dangerous consequences and desired their occurrence.

2. The purpose of the person - the realization of actions (inaction) directly aimed at the committing of the offense with direct intent and bring the crime to the end.

The subject of the criminal attempt - a sane person over at the time of committing the crime of criminal responsibility age. In addition, in the characterization of the act it is worth noting that the criminal attempt is possible only by a person possessing all the attributes of the subject of this type of crime. The only foundation of criminal responsibility - it is the presence of a socially dangerous act all the elements of the offense. If the criminal attempt do not have all the mandatory characteristics of the offense, respectively, there is no reason to bring the committer of the assassination to criminal justice. However, when making the criminal attempt for the recognition of a crime is not necessary offensive damage or criminal result. Therefore, in this connection, it opinion that in an

\footnotetext{
${ }^{1}$ The Resolution of the Supreme Court Plenum of the Republic of Uzbekistan (24.09.2004) “About judicial practice of intentional
} killing” №13 
criminal attempt existing member of all elements of a crime other than the consequences. In the criminal attempt the offender does not have time to make all the signs that characterize the objective side of the completed offense itself. However, in a criminal attempt there are all mandatory elements of the offense.

So, criminal attempt has all the required elements of the crime - the object, the objective side, the subject and the subjective side. The presence in the act of a person signs a separate crime are foundation for criminal responsibility for criminal attempt.

Based on the foregoing, we can give the following definition of the concept of criminal attempt, "Getting commit a crime with direct intent when socially dangerous action or inaction, interrupted before the commission thereof due to circumstances not depending of a committer, is not satisfied in full, or does not occur criminal result, the desired person recognizes as a criminal attempt. "

Despite the Criminal Code of the Republic of Uzbekistan has the definition of the concept of criminal attempt, there is no its types and forms. In the theory of criminal law stand completed and un completed, fit and unfit types of attempts.

"It is worth point that, in reality, when qualifying actions separation criminal attempt on types does not matter, but it is important for individualization of punishment, so the types of attempt do not stand out in the Criminal Code ${ }^{1}$." "It kind of attempt to allocate based on the possibility of voluntary renunciation on the stage of preparation for a crime and attempted crime"2; "When delimitation of attempt of voluntary renunciation of the commission of the crime, is of practical importance and completed and uncompleted kinds of attacks"; "It is important in determining the degree of public danger of the offense and sentencing"; Finally, "a completed attempt usually has a higher degree of danger to society, because it is very close to the completed crime stage, respectively, the punishment should be more severe." ${ }^{\prime 3}$. Consequently, the classification of the criminal attempt, the delimitation of species, has important theoretical and practical significance.

\section{Types of criminal attempt}

Division of attempt to commit a crime on the types based on certain criteria. This problem is solved by means of the subjective criterion (subjective perception of the person on the extent of the completion of criminal intent $)^{4}$,, objective criteria (the degree of completion of all actions committed by the guilty) ${ }^{5}$ or mixed criteria.

In our view, the resolution of the question of whether the attempt as completed or incomplete, it is important not to the degree of criminal intent, the objective side of the crime, but the implementation of the subject of all the necessary actions to advance criminal result. That is, what matters is not the outer side face of conduct and internal the subjective side. Therefore, the delimitation of criminal attempt on the completed and uncompleted should be based on a subjective criterion.

At the completed attempt person performs all of the dependent actions necessary to complete the offense, considers that these actions enough to end the crime and do not need to perform any additional actions. However, for objective reasons, the crime is not brought to the end.

If a person, for reasons beyond its control, does not carry out all the actions (inaction) which are necessary to achieve the criminal result, the act recognizes the uncompleted attempt.

The terms "the unfit attempt", " unfit object", " unfit measures" are conditional. The essence unfit attempt and its types is that the person appears erroneous judgment regarding these or other terms, conditions or situations. Therefore, the legal nature of unfit attempt should be considered from the point of view of the actual errors and its criminally-legal doctrine.

\footnotetext{
${ }^{1}$ Kozlov A.P. The doctrine on stages of crime. -Saint Petersburg. -P. 289.

${ }^{2}$ Nazarenko A.G., Sitnikova A.I. Unfinished crimes and its types: Monograph. -M.: OS-89, 2003. -P. 108; Anisimov A.A. Unfinished crimes and the proving specifics. Dissertation. 2003. -P.51-52.

${ }^{3}$ Anisimov A.A. Unfinished crimes and the proving specifics. Dissertation. 2003. -P.51-52.

${ }^{4}$ Criminal Law. Textbook. -Tashkent: The Academy of MIA of the Republic of Uzbekistan, 2012. -P. 225.

${ }^{5}$ Rustambayev M.X. The Republic of Uzbekistan Criminal Law course. -Tashkent. Ilm Ziyo. 2010, P.249.
} 
In general, despite the fact that the doctrine of criminal law expressed different ideas about the kinds of unfit attempts, and its impact on the qualification of the act, scientists have not reached a consensus on this issue. Thus, the legal value of unfit attempt is that, first, when a worn attempted unlike the completed and uncompleted attempts, it was not communicated to the end because of mistakes a person; secondly, unfit attempt is a concept directly related to the subjective side of crime; Third, in some cases, unfit attempt does not entail criminal responsibility.

Unfit attempt can be complete or incomplete, it is the essence of a person mistake in choosing the means or object (the object) to commit a crime. In determining the liability for unfit attempt must be based on the presence or absence of social danger of acts. Unfit attempt is divided into a attempt with useless objects (object) or measures.

In our view, a division of the finished and unfinished attempt on the kinds of unfit attempt has important theoretical and practical significance. So, when the criminal attempt on the unfit object is not an act communicated to the end as a result of the actual fault of person. The reason not complete crime until the end is a misconception about the face of public relations, directed criminal attempt. Although in such cases, the harm certain social relations do not cause, even there is no threat of causing, criminal responsibility for intent faces. It should be noted that there is no question that the responsibility comes for the thoughts a person prohibited by international standards. The basis of criminal responsibility for these kinds of acts is committing acts. In this regard, in accordance with Article 14 of the Criminal Code, socially dangerous act is recognized, which causes or creates a real threat of damage to the objects protected by the Criminal Code. When attempted useless objects, the object is not harmed, not even a real threat of harm. Since, in this situation is not the public relations, protected by criminal law.

Secondly, although this view is put forward, most legal scholars, in our view, the use of "unfit object" inappropriate concepts. In particular, the object of the crime is an mandatory element constituting the basis of criminal responsibility, the absence excludes liability. In any situation, public relations, protected by criminal law, should be fit.

For this reason, in our opinion, although the attempt on the unfit object is intent entity aimed at committing an offense and is expressed in the commission of certain actions, public relations are not harmed, however, criminal liability shall not come.

\section{Sentencing for committing criminal attempt}

In Uzbekistan, the liberalization of the judicial system consistently and gradually implemented, including the system of criminal penalties. Introduction of the institute of reconciliation, exception confiscation of criminal punishment system, abolition of the death penalty as a criminal punishment, the possibility of appointing a life sentence for the two types of crime an integral part of reforms in the system of penalties. On the basis of the law of 10 August 2015 "On amendments and additions to some legislative acts of the Republic of Uzbekistan" has been implemented a new kind of punishment alternative to imprisonment - the restriction of freedom.

It is worth noting that as a form of expression of humanism principle of national criminal law, you can specify the article 58 of the Criminal Code. This article deals with the appointment of punishment for preparation of a crime and criminal attempt. It should be emphasized that at the time of the adoption of the Criminal Code provides for the appointment of equal punishment for the completed and uncompleted crimes. Thus, the fixed rule that the appointment of punishment for uncompleted crime court, guided by the general principles of sentencing, also takes into account the gravity of the crime, the degree of realization of criminal intent and the reasons due to which the crime was not completed.

April 11, 2008, adopted the Law of the Republic of Uzbekistan "On Amending Article 58 of the Criminal Code of the Republic of Uzbekistan". In accordance with Article 58 of the Criminal Code was supplemented with part two as follows:

"Term or measure of punishment for preparation of a crime and attempted crime can not exceed three quarters of the maximum punishment provided by appropriate article of the Special Part of this Code. This rule does not apply in sentencing:

a) to especially dangerous recidivists, members of an organized group or criminal community;

b) for an uncompleted crime against peace and security, as well as related offenses:

intentional killing with aggravating circumstances; 
rape or violent sexual satisfaction of the needs of unnatural against the victim, known to the committer has not attained the age of fourteen;

smuggling of nuclear, chemical, biological and other weapons of mass destruction, materials and equipment of radioactive materials that could obviously be used in its creation."'1 .

It is worth noting that this law has led to a radical change in the practice of punishment for uncompleted crime. This law helps to ensure the principle of differentiation and individualization of punishment in sentencing for the preparation of a crime or criminal attempt intended milder punishment for uncompleted crime, in particular the reduction of the maximum term (the size) of punishment for uncompleted crime. If, in accordance with the former law should refer to article 25 of the Criminal Code in sentencing for uncompleted crime, the legal consequences are not taken into account. After the adoption of this law on the judicial and investigating authorities were obliged to take into account Article 25 of the Criminal Code as a condition of qualification and thus reduce the period of time (the size of) punishment.

Responsibility for the preparation of a crime is solved in accordance with the norm of the Criminal Code, defines the responsibilities of the offense itself. The rules of the articles of the Criminal Code provides for liability only for a completed crimes, article 25 is a "special", which provides for liability for an uncompleted crimes. Therefore, when preparing the qualification of a crime or criminal attempt must use this norm. Although this procedure is not provided separately in the law, there was a similar positive experience in judicial and investigative practice.

In our opinion, when qualifying uncompleted crimes should take into account the degree of its public danger. So, if in the preparation of a crime, there is no threat of harm to the object of crime, in a criminal attempt is a real threat of harm or damage is caused; in the preparation of the crime act specified in the disposition of the article of the Special Part, is not performed, that is not a crime begins, in criminal attempt, an act referred to in the disposition of the article of the Special Part, committed, has the criminal result.

Therefore it is necessary to distinguish the preparation of a crime and criminal attempt. Delimitation unfinished crimes contributes to the principle of differentiation and individualization of punishment in sentencing for the preparation of a crime or criminal attempt intended milder punishments for preparation of a crime as opposed to the criminal attempt.

In the appointment of punishment for uncompleted crime, the court in addition to the general principles of sentencing must take into account the severity of the crime, the degree of implementation of criminal intent and the reasons due to which the crime was not completed.

General principles of sentencing referred to in article 54 of the Criminal Code, in accordance with it, f person shall be subjected to penalty, if he, according to the procedure established by law, is found guilty in commission of a crime. A court shall inflict a penalty within the limits established by an Article of the Special Part envisaging liability for a crime committed, in accordance with provisions of the General Part of this Code.

It should be noted that in the Article 25 of the Criminal Code, there are different definitions of types of unfinished crime, the preparation of the crime or criminal attempt, and their legal consequences are the same. No necessity even their delimitation in qualifying unfinished crimes indicate separately the relevant parts of Article 25 of the Criminal Code. Because, for the preparation of a crime and criminal attempt is assigned the same punishment. However, the degree of public danger of the preparations different from the extent and nature of public danger of the criminal attempt. In the preparation of the crime harm public relations, protected by law not to cause only there is a threat of such damage crime itself has not yet begun, the action or inaction referred to in the disposition of the article of the Criminal Code is not fulfilled.

Therefore, in our opinion, should be paid to these circumstances and to appoint punishment for preparation of a crime in a smaller size as compared to the attempted crime. In particular, the second part of Article 58 of the Criminal Code should be amended as follows: "Term or measure of punishment for preparation of a crime can not exceed one-half of the punishment provided by the corresponding article of the Special Part of Criminal Code, a

\footnotetext{
${ }^{1}$ The Digest of Law of the Republic of Uzbekistan,, 2008 y., №16, Article 116.
} 
term or amount of punishment for a criminal attempt can not exceed two-thirds of the punishment provided by the corresponding article of the Special Part of Criminal Code".

In addition, based on the fact that the preparation of the crime has no criminal consequences, in our opinion, provided for in Paragraph 3 of Article 58 of the Criminal Code excluding circumstances should not be applied to the preparation of the crime.

In our view, the proposed change may be a useful in continuing the policy of liberalization of criminal law, will contribute to the differentiation of punishment for a criminal attempt, individualization of punishment, sentencing based on the degree of public danger of the act, thus providing a true principle of fairness in the criminal law.

\section{References:}

1. The Constitution of the Republic of Uzbekistan (amended March 2016)

2. The Criminal Code of the Republic of Uzbekistan (amended March 2016)

3. Gaur K.D. , " Indian Penal Code" Chap.XXIII p. 842

4. Attempt in Criminal law. By Suwarn Rajan, Advocate, Supreme Court of India. Published in Criminal Law Journal.

5. Rustambayev M.X. The Republic of Uzbekistan Criminal Law course. -Tashkent. Ilm Ziyo. 2010, P.246.

6. Usmonaliyev M. The composition of offense (corpus delicti). -Tashkent: TSIL, 2008. -P.8.

7. Turgunboyev E.O. The foundation of qualifing act as a criminal attempt // The bulletin of Supreme Court of the Republic of Uzbekistan. 2008, №5. -P.35.

8. Rajib Hassan The Elements and Stages of a Crime An Overview.

9. The Resolution of the Supreme Court Plenum of the Republic of Uzbekistan (24.09.2004) "About judicial practice of intentional killing” №13.

10. Kozlov A.P. The doctrine on stages of crime. -Saint Petersburg. -P. 289.

11. Nazarenko A.G., Sitnikova A.I. Unfinished crimes and its types: Monograph. -M.: OS-89, 2003. -P. 108.

12. Anisimov A.A. Unfinished crimes and the proving specifics. Dissertation. 2003. -P.51-52.

13. Criminal Law. Textbook. -Tashkent: The Academy of MIA of the Republic of Uzbekistan, 2012. -P. 225.

14. The Digest of Law of the Republic of Uzbekistan, 2008 y., №16, Article 116. 